\begin{tabular}{|c|c|c|c|}
\hline 水 蒸 気 & $\left(200 \mathrm{lb} / \mathrm{in}^{2}\right)$ & $1 b$ & 32,000 \\
\hline " & $\left(30 \mathrm{lb} / \mathrm{in}^{2}\right)$ & " & 48,000 \\
\hline 電 & & $\mathrm{KWH}$ & 170 \\
\hline 却 水 & & gal & 87,000 \\
\hline カセイソーダ & & $1 b$ & 150 \\
\hline ×夕ノ一ル & & gal & 9 \\
\hline
\end{tabular}

V. 結語

ユニゾール脱硫装置は種々の利点があり, 運転状沉も 良好である。さらに適正運転条件の検索につとめたいと 考光ている。運転開始後, 間子ないため装置の腐食など そついては，今後の問題である。わが国最初の装置であ るから，石油精製技術のためにいく分でも参考となれば 幸でめる。
（昭和 32 年 12 月 21 日受理）

\title{
石油工業における表面活性剈の動向
}

\author{
叫本 晴 次*
}

\section{A Trend of Application of Surface Active Agents in Petroleum Industry}

\section{Haruzi YAMAMOTO}

\section{I. むえがき}

近年石油製品の品質が著しく向上し, 需要が増大して きた。これらの石油製品江要求される性質のすべてを満 足するような理想的な物理, 化学的な性質を持ったもの が製造されるならば添加剤の必要はないが，今日では添 加剤なしにはこれらの要求を満足するようなるのの生産 を増加し，コストの低下をはかって製造することができ ないといってる過言ではなく, 製品の品質を確保し， service performance の向上をはかるため江多くの添加 剤が使用されている。すた石油工業と郝けるこのような 添加剂の使用技術の進歩は界面化学の分野の著しい進歩 とあいまって化学工業の重要な一環をなす表面活性剤製 造工業の発達淿大い学ずかって力がある。ここでは石 油添加剂使用の動向と表面活性剂応用の一, 二の例を紹 介する。

\section{II. 石油添加 剤}

わが国の石油添加剤の消費は年々増加の一途をたど り，四エチル鉛を除いて約 2,000 トンくらいが年間消費 されている。これらの石油添加剤は大部分米国からの輸 入依存しているぼかりがなく，その応用垱当っても米 国の影響を著しく受けている。したがってわが国の石油

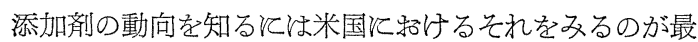
る手取りばやい方法である。

\section{1. 燃料油添加剂}

表- ${ }^{6)}$ は米国飞括いて市販されている燃料油添加凨の 種類と代表的な使用量呿よび推定消費量で，四エチル 鉛, 承結防止剤, 気筒壁潤滑剂を除くと，との消費はま
だきわめて貧弱である。これらの添加剤の作用とついて の基礎知識や実際の效果を決定するのははなはだ困難で めるが，これらのうち気筒壁潤滑剤，拡散剤，窝食防止 凬などは表面作用によると考党られている。気筒壁潤滑 剤はここ数年前からわが国にる紹介され，内燃機関シリ ンダーの上部の潤滑やカーボンの除去のためにしばしば 用いられているがとの実際上の效果礼いては明らかで ない。しかしこれらのあるものは塩素化芳香族化合物と インヒビターと潤滑油とから成り，然料の吸気系統中に 生じた析出物を除去するには役立つように思われるが， 最近ではこの目的に適した清浄剤が用いられている。 わが国ではほとえでが直留軽油で，分解軽油はまだそう 多くは用いられていないため，米国皂で問題にされてい ないが，スラッシの生成や凝集のためにオイルバーナ一 やディーゼルフィルターのスクリーンを詰め, 燃焼上種 々の障害を起すととが慧められ，この防止飞拡散安定剂 が用いられている。これらの拡散安定剤のあるものは表 面活性剂と溶解剤（solutizer）とを適当纪組合わせたる ので他のるのはラウリルメタクリレート/ジエチルアミ ノエチルメタクリレート (80:20) のような塩基性の重 合物 ${ }^{1)}$ が用いられているが，ふつうの酸化防止剂ではこ れを防止することはできない。をた燃料油を眝蔵する際 そもしばしば寉食が問題となっているが，これは単に睦 蔵容器を腐食するだけでなく，生じたさびがわずかでも

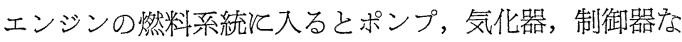

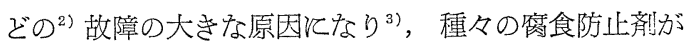
用いられている。たとえば有機りン化合物, アミン類, 石油スルホン酸の塩類, 酸化パラフィンワックスあるい はナフテン酸なぞのエステル，ソルビタントリオレエー 
表-1 米国飞和ける燃料油添加剂の推定消費量

\begin{tabular}{|c|c|c|c|c|c|c|c|c|}
\hline & \multirow{2}{*}{ 添 加 剂 } & \multirow{2}{*}{ 添 加 量 } & \multicolumn{2}{|c|}{1954} & \multicolumn{2}{|c|}{1955} & \multicolumn{2}{|c|}{1956} \\
\hline & & & $\begin{array}{c}100 \text { 万 } \\
1 \mathrm{~b}\end{array}$ & $\begin{array}{cc}100 & \text { 万 } \\
\text { ド } & \text { ル }\end{array}$ & $\begin{array}{c}100 \text { 万 } \\
1 \mathrm{~b}\end{array}$ & $\begin{array}{cc}100 & \text { 万 } \\
ト ゙ & \text { ル }\end{array}$ & $\begin{array}{c}100 \text { 万 } \\
1 \mathrm{~b}\end{array}$ & 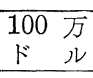 \\
\hline \multirow{8}{*}{ ガソリン } & 四エチル 鉛 & $3 \mathrm{cc} / \mathrm{gal}(\max )$ & 350 & 225 & $400 \sim 450$ & 250 & - & 260 \\
\hline & 酸 化 防 止 剂 & $2 \sim 16 \mathrm{lb} / 1000 \mathrm{bbl}$ & 5.5 & 6 & 6 & 7 & - & 7 \\
\hline & 金属不活性剂 & $1 \sim 3 \mathrm{lb} / 1000 \mathrm{bbl}$ & 0.75 & 1.4 & 1.5 & 2 & - & 2 \\
\hline & さび止め剂 & $10 \sim 50 \mathrm{ppm}$ & - & - & 5 & 1 & - & 1 \\
\hline & 水結 防 止剂 & $1 \%$ & - & - & 190 & 10 & - & 10 \\
\hline & 掃 気 剂 & $0.01 \sim 0.02 \%$ & - & - & 8 & 3 & - & 4 \\
\hline & 気筒壁潤滑剤 & $2500 \mathrm{ppm}$ & - & - & 140 & 5 & - & 6 \\
\hline & 着色 剂 & $5 \mathrm{ppm}$ & - & - & 1 & 1 & - & 2 \\
\hline \multirow{3}{*}{$\underset{\text { 然 }}{シ \text { 料 }}$} & 酸化防止剂 & $20 \mathrm{ppm}$ & - & - & - & - & - & - \\
\hline & 金属不活 性 剂 & $4 \mathrm{ppm}$ & - & - & - & - & - & - \\
\hline & さび止め剤 & $50 \mathrm{ppm}$ & - & 一 & - & - & - & - \\
\hline \multirow{2}{*}{$\begin{array}{l}\text { ディ一ゼ } \\
\text { ル 然料 }\end{array}$} & 拡散安 定剂 & $20 \sim 50 \mathrm{lb} / 1000 \mathrm{bbl}$ & 10 & $3 \sim 5$ & 12 & $4 \sim 6$ & - & - \\
\hline & セタン価向上剤 & $0.1 \sim 0.3 \%$ & - & - & 1 & 0.3 & - & - \\
\hline \multirow{4}{*}{ 重 油 } & 助 燃 剂 & $50 \mathrm{ppm}$ & - & - & - & - & - & - \\
\hline & 拡散安 定 剂 & $100 \mathrm{ppm}$ & - & - & - & - & - & 3 \\
\hline & 灰 分 緩 和 剂 & $500 \mathrm{ppm}$ & - & - & - & - & - & - \\
\hline & さび止め剤 & $50 \mathrm{ppm}$ & - & - & - & - & - & - \\
\hline 合計 & & & 366.25 & $\begin{array}{l}235.4 \\
\sim 237.4\end{array}$ & $\begin{array}{l}764.5 \\
\sim 814.5\end{array}$ & $\begin{array}{l}283.3 \\
\sim 285.3\end{array}$ & - & 295 \\
\hline
\end{tabular}

ト, アシドイミダゾリン塩, 気相でさび止め効果を発揮 するイソプロピルアンモニウムナイトライト，ジシクロ ヘキシルアンモニウムエチルホスフェート，エチルモル ホリンベンゾエート4)などがある。

表-2 米国に扣ける潤滑油添加剂の推定消費量

\begin{tabular}{|c|c|c|c|c|c|c|c|c|}
\hline \multirow{2}{*}{ 添加剂 添加量 } & \multicolumn{2}{|c|}{1954} & \multicolumn{2}{|c|}{1955} & \multicolumn{2}{|c|}{1956} & \multicolumn{2}{|c|}{1960} \\
\hline & $\begin{array}{c}100 \text { 万 } \\
\mathrm{lb}\end{array}$ & $\begin{array}{c}100 \text { 万 } \\
\text { ドル }\end{array}$ & $\begin{array}{c}100 \text { 万 } \\
1 \mathrm{~b}\end{array}$ & $\begin{array}{c}100 \text { 万 } \\
\text { ドル }\end{array}$ & $\begin{array}{c}100 \text { 万 } \\
1 \mathrm{~b}\end{array}$ & $\begin{array}{c}100 \text { 万 } \\
\text { ドル }\end{array}$ & $\begin{array}{c}100 \text { 万 } \\
1 \mathrm{~b}\end{array}$ & $\begin{array}{l}100 \text { 万 } \\
\text { ドル }\end{array}$ \\
\hline 清 浄 剂 $2 \sim 10 \%$ & 250 & 50 & $280 \sim 300$ & 57 & 290 & 66 & 350 & - \\
\hline 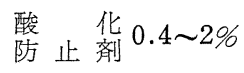 & 60 & 12 & $70 \sim 75$ & 15 & 73 & 22 & 78 & - \\
\hline $\begin{array}{l}\text { 粘度指数 } 0.5 \\
\text { 向上 剂 } 10 \%\end{array}$ & 50 & 13 & $60 \sim 65$ & 15 & 148 & 31 & 221 & - \\
\hline 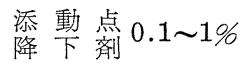 & 5 & 2 & 5 & 2 & 29 & 12 & 30 & 一 \\
\hline 極 加 剂 $5 \sim 10 \%$ & 50 & 13 & 60 & 14 & 59 & 16 & 65 & - \\
\hline $\begin{array}{l}\text { 油 性 } 0.1 \sim 1 \% \\
\text { 向上剂 }\end{array}$ & - & 10 & - & - & & 3 & & - \\
\hline $\begin{array}{l}\text { 㐫 } 0.0002 \\
\text { 消乙剂 } \sim 0.07 \%\end{array}$ & - & - & - & - & - & 一 & - & - \\
\hline さび止め $0.1 \sim 1 \%$ & - & - & - & - & - & - & - & - \\
\hline 着色剂 $0.1 \sim 1 \%$ & - & - & - & - & - & 一 & - & - \\
\hline 合 & 415 & 100 & $475 \sim 505$ & 103 & 599 & 150 & 744 & - \\
\hline
\end{tabular}

2. 潤滑油添加剂

表-2 は最近の米国に捈ける特もな潤滑油添加剤の推 定消費量および推定消費額で，清浄剤拉よび粘度指数向 上剂（流動点降下剂と清浄とをかねたものを含める）の

表-3 清浄剂のタイプの推定消

\begin{tabular}{|c|c|c|c|c|}
\hline 年 & $\begin{array}{l}\text { スルホ } \\
\text { ン酸塩 }\end{array}$ & $\begin{array}{l}\text { フェネ } \\
-\quad 卜 \\
\end{array}$ & その他 & 合計 \\
\hline 1955 & 135 & 130 & 10 & 275 \\
\hline 1956 & 145 & 132 & 13 & 290 \\
\hline 1960 & 160 & 135 & 55 & 350 \\
\hline
\end{tabular}

表-4 粘度指数向上剂の推定消費量

\begin{tabular}{|c|c|c|c|c|}
\hline 年 & $\begin{array}{l}\text { マルチ } \\
\text { グレー } \\
\text { ド油 }\end{array}$ & $\mid \begin{array}{l}\text { ビーー } \\
\text { ディニ } \\
\text { ティィー } \\
\text { 油 }\end{array}$ & $\begin{array}{l}\text { オートマテ } \\
\text { イックトラ } \\
\text { ンスるッシ } \\
\text { ョン }\end{array}$ & 合計 \\
\hline & 75 & 45 & 3 & 123 \\
\hline & 95 & 50 & 3 & 148 \\
\hline 1960 & 140 & 37 & 4 & 18 \\
\hline
\end{tabular}

表-5 粘度指数向上剂のタイプ

\begin{tabular}{|c|c|c|c|c|}
\hline 年 & $\begin{array}{l}\text { ポリメタ } \\
\text { クリレー } \\
ト\end{array}$ & その他 & \begin{tabular}{|l} 
塩基性含 \\
至素重合 \\
物
\end{tabular} & 合計 \\
\hline & 66 & 54 & 0 & 120 \\
\hline & 77 & 61 & 1 & 139 \\
\hline & 105 & 75 & 40 & 22 \\
\hline
\end{tabular}


消費が増大している。これは自動車エンジンの出力の増 大, エンジンの小型化, 仕上げ精度の向上飞とるない運 転条件も燃料のイオウ分の増大, 速度変化も高速, 低速 の幅が広くなり，連続的な負荷ばかりでなく衝撃的な負 荷を受け, 気候的な温度範囲も拡大され, stop and go のよろとエンジンのきびしさが増大し，潤滑油に対する 負担が重くなってきた。このためとエンジンの高度の清 浄性が要求され, 表-3 $\left.3^{6}\right)$ のよう飞清浄剤の使用量が増加 してきた。清浄剤の使用はその表面活性作用と基づくと 考光られ大部分がカルシウムあるいはバリウムのスルホ ン酸塩とフェネートで, 前者の使用量がいくらか増加 乙, 舶用としては塩基性の清浄版が多く用いられ, カル シウム塩の方がよいといわれている。

また使用油の粘度も低粘度油へと移行し, 表 $-4^{6>}$ のと 拉りわが国の市場㳊すすで紹介ずみのいわゆる SAE/ $10 \mathrm{~W}-30,20 \mathrm{~W}-40$ のような広い温度範囲をカバーす るマルチグレード油が生れ, 高温のスラッジの防止の要 求ととも亿低温スラッジの防止という新しい要求が生れ てきた。これらの要求を満たすために表一らのよろな粘 度指数向上剤が用いられている。粘度指数向上剂として はポリブテンのような重合物やポリメタクリレートのよ うなものが用いられ, 最近と扮いて山後者の使用量が増 加している。粘度指数向上剂の作用は表面活性作用飞基 づくものではないが，ポリメタリレートのあるものは粘 度指数向上剂の作用之同時飞表面活性作用飞基づくと考 えられる流動点降下剤の作用を有している。またうウり ルメタクリレート/ジエチルアミノメタクリレート (90: 10）のよう飞塩基性の窒素を含有する重合物は粘度指数 の向上, 流動点の降下の作用を有する注か stop and go のよろな条件下飞生ずる低温スラッジの防止という要求 を満たす新しいタイプの清浄剤で, 漸次使用量が増加す る傾向がある。その他さび止め油, 切削油, 圧延油, グ リース, ワックスエマルジョンなどの製造にも多くの表 面活性剤が用いられているが，ここでは省略する。

\section{3. アスファルト添加剤}

わが国の道路舗装についていつも論議されるのがコン クリート舗装か，アスファルト舗装かという問題である が，適当なアスファルト猞装を施行するととにより長年 月汸たり，少しもいたむととなく使用されている例が あり, わが国の現状からみて豊富な中東系原油からの安 価な品質のよいアスファルトの供給とあいまって舗装技 術の進歩がもたらされればアスファルト舗装も有利とな り, 中東系原油からのアスファルトの品質向上が望委れ ている。アスファルト自体が一つの分散系をなしている からアスファルトを道路の舗装, ルーフィングなどに使 用する場合，骨材なでをアスファルトで被う現象は一つ の表面活性現像で，アスファルトと骨材間々強い安定な 結合を作ることが必要である。これねはこれらの間の界
面張力を低下させることとよりぬれを促進させれね゙強い 結合を作ることができる。このためと表面活性剤が用い られこれを助けている。これとはらつうセッケン, 清浄剤 などが用いられている。またアスファルトは雨水, 湿度 なぞ和かされ，粘着力を失ったりするため，粘着力を 確保するよろな添加剤やきれつを防止したり，はく離を 防止するような添加剤が用いられている。前者は bonding agent と呼ばれ，脂肪酸のアミドなどが用いられ， 後者は anticracking and antistripping agent と呼ね゙ れ，石油スルホン酸塩などが用いられ，これを用いるこ とにより可塑性が増大する。このほか現在問題となって いるのは中東系原油からのアスファルトの乳化で, これ を満足するような表面活性剤の研究が望おれている。

\section{III. プロセシングにおける表面活性剤 の応用}

石油の精製過程たとえぼ原油の脱水, 脱塩, 原油の蒸 留の際和ける装置の窝食防止，潤滑油などの硫酸精製 そ和ける中和の際に和けるエマルジョンの破壞, 使用中 そ起るエマルジョンの破壊, ドラム, パイプ, 容器の洗 浄招よび加熱発熱交換器, ボイラーなぞ装置の洗浄など と各種の表面活性剂が用いられ，とれぞれ効果をあげ ていることはよく知られていると物りで，ここではロウ を含えだ潤滑油から低流動点の潤滑油を得る脱口ウ工程 飞表面活性剤を利用した新しい脱口ウ法を紹介する。ら つうロウを含んだ流動点の高い潤滑油から口ウ分を分離 するため最近では溶剤脱口ウ法が用いられているが， 脱口ウ油の収率を上げるためとはな和改良の余地があ

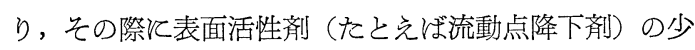
量を用いるとよいことが知られているが，最近 Shell Laboratoryで新しく改良された SAA 法（Surface Ac-

表-6 接触角々脱口ウ溶剂組成の变化

測定条件 温度 $20^{\circ} \mathrm{C}$ 炭化水素油相中の油の濃度 $\quad 10 \mathrm{wt} \%$ nーヘプタデシルー9-硫酸ナトリウム 水溶液濃度 $0.2 \mathrm{~g} / \mathrm{l}$ 硫酸ナトリウム水溶液濃度 $\quad 0.2 \mathrm{~g} / \mathrm{l}$

\begin{tabular}{c|c}
\hline ベンゼン/メチルルケトン重量比 & 接触角 (油相上) \\
\hline $50 / 50$ & $88^{\circ}$ \\
$60 / 40$ & $115^{\circ}$ \\
$70 / 30$ & $157^{\circ}$ \\
$80 / 20$ & $130^{\circ}$ \\
$90 / 10$ & $90^{\circ}$ \\
\hline トルエン/×チル & \\
\hline エチルケトン重量比 & \\
\hline $60 / 40$ & $90^{\circ}$ \\
$70 / 30$ & $130^{\circ}$ \\
$80 / 20$ & $145^{\circ}$ \\
$90 / 10$ & $98^{\circ}$ \\
\hline
\end{tabular}




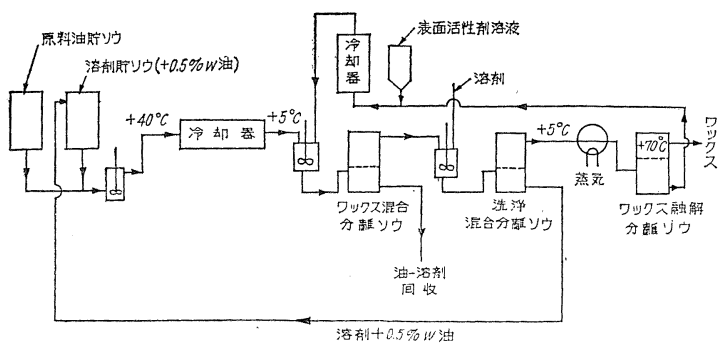

図-1

tive Agent Dewaxing Method) ${ }^{5)}$ が生れた。この原理 は油/溶剤相からぬれの反転 (wetting reversal) 現象 を利用することとより水岕るいは水溶液の相へ結晶した ワックスを移し，ワックスを分離する方法で，含油量 $0.3 \%$ のワックスが得られ，脱油の収率を上げることが できると報告されている。な特この溶郕としてね 1,2

表-7 パイロットプラントの運転結果

試験条件 温度 $\quad+5^{\circ} \mathrm{C}$

溶剂1,2-ジクロルエタン (DCE)

含口门油通油量 $\quad 10 \sim 22^{1} / 2 l / h r$

溶剂/油重量比 $3 / 1$

水溶液/溶剂混合油 容量比 $1.5 \sim 2.0$

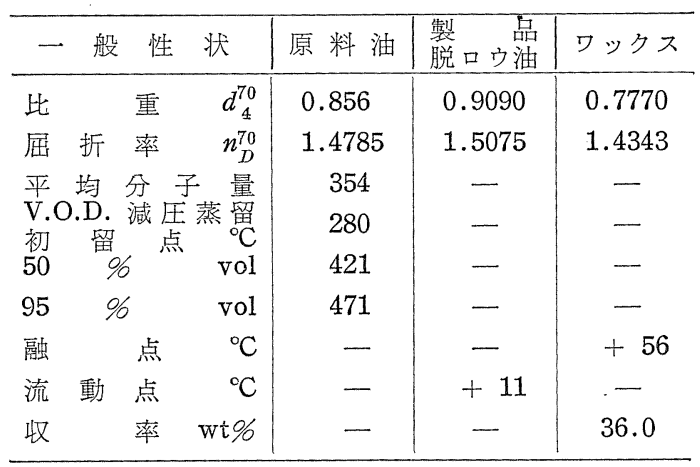

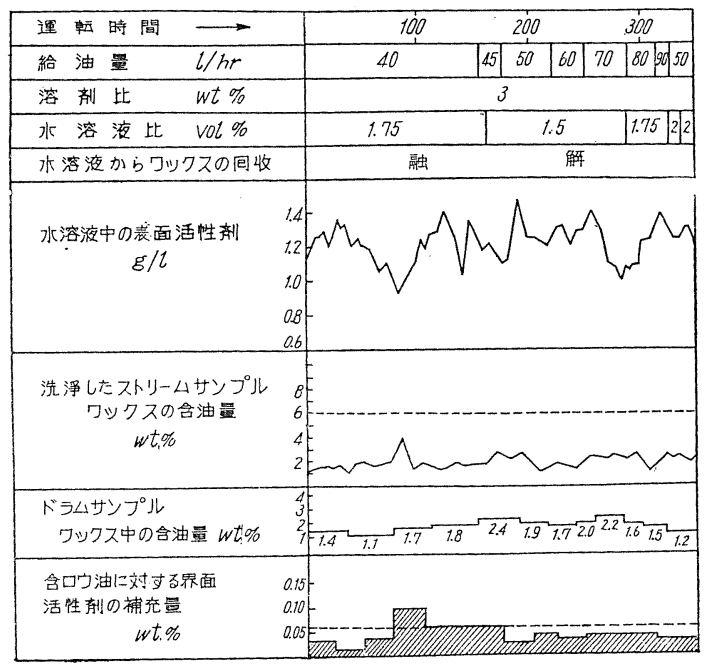

ージクロルエタンが最もよいといわれている。ぬれの 反転の現象は多くの因子たとえば溶剤の組成, 溶郕/ 油の比, 表面活性剤の性質, 水溶液の組成拉よび $\mathrm{pH}$ 温度, 油中のワックスの性質なぞ界面張力に影響する すべてにより影響される。その一例をあげれば 表一6 のと和りである。図-1 はパイロットプラントの簡単 な系統図でその結果の一例を表-7 亿示した。これは $5^{\circ} \mathrm{C}$ で脱口ウを行った結果であるが，より低い流動点 の潤滑油を得るためには $-10^{\circ} \mathrm{C}$ 委で脱口ウが可能で あるといわれている。本法の特徴ねフィルターを用い ない連続的な脱口ウ法で, その経済性性用する表面活 性剤の損失飞大きく支配され，この損失は $0.1 \%$ 以内で めればよいといわれ，パイロットプラントの結果では約 0.05\%損失で，これを随時補給している。

\section{IV. その他の応用}

最近潤滑管理の必要が叫ばれてから著しく潤滑技術が 向上したが，現場で最も望まれていることは使用油の交 換時期をいらにしたらよいかを容易に予知することで， このよろな分析面住対しても表面活性作用の応用が認め られている。その一例として清浄剤を含んだ潤滑油の交 換時期の判定に，清浄剤の表面活性作用を利用し，この 機能の低下をスポット試験将より判定するととが行われ ているほか, とのアルカリ残留能力を指示楽により直接 判定しやすくするようと表面活性剤の作用を利用する方 法がこうじられ，ある程度との成果が認められるようと なってきた。

\section{V.むすび}

以上石油工業飞和ける表面活性剤の動向と一, 二の応 用例飞ついて紹介したが，な持多くの研究すべき問題が 残され，今後ますます界面化学の分野の力を借りなけれ マ゙よりよい製品への品質向上，コストの低下，生産の向 上を期待するることは不可能で, 界面化学の基礎応用の 研究ととも《表面活性剤の製造技術の向上が望皂れる。

（昭和 33 年 2 月 14 日受理）

$$
\text { 文献 }
$$

1) C.B. Biswell, W.E. Catlin, J.F. Froning, G.B Robbins, 125th National Meeting American Society Kansas City Mission, March 23 April 1 (1954)

2) F.M. Watkins, 3rd World Pet., VIII 86 (1951)

3) N. Hackerman, A.H. Roebuck, Ind. Eng. Chem. 48, 1481 (1954)

4) H.R. Baker, Ind. Eng. Chem., 46, 2592 (1954)

5） H. Mondria，第 2 回世界界面活性剂会議 VI (a) (1957)

6) Robert S. Aries, A Symposium on Additive in Lubricants Division of Petroleum Chemistry American Chemical Society Atlantic City Meeting. Sept. 17 21, 1956 preprint Vol.1 No.4 p. 5 